\title{
How will the Health Literacy and Crowded Emergency Room Be Affected After the COVID-19 Pandemic?
}

COVID-19 Pandemisinden Sonra Sağlık Okuryazarlığı ve Kalabalık Acil Servisler Nasıl Etkilenecek?

\author{
iDserdar Ozdemir, iDAbdullah Algin
}

University of Health Sciences, Umraniye Training and Research Hospital, Department of Emergency Medicine ,Istanbul, Turkey.

Health literacy evaluates a person's ability to read the information and tables about health, to use the proper gadgets related to personal and family health, to calculate the right timing and dosage of prescribed drugs, to participate in research, and to comment about health-related and environmental policies. The concept of health literacy, which was first used by Scott K. Simonds in 1974, is used in international literature more and more every day (1). The term has been rarely used for 25 years, but after this period, it has started to be used intensively in America and Europe and it has been the subject of many studies ever since (1). The low level of health literacy is a public health problem worldwide. Especially the populations who are below average in socioeconomic status are more prone to having low health literacy (1).

Sometimes emergency department patients and their relatives have to make quick and important decisions about their suddenly developed or newly diagnosed health problems. Health literacy affects the patient-physician relationship, the perception of the newly developed health situation, and the decision to be taken with regards to this situation. According to the current literature, it is highly recommended to increase health literacy in order to prevent negative outcomes, to increase compliance with physician's recommendations and to decrease subsequent visits to the emergency department (2).

Coronavirus 2019 (COVID-19), was identified for the first time on December 31, 2019 as an airborne disease and declared as a pandemic by the World Health Organization on March 11, 2020 (3). During the pandemic, governments took different approaches in order to prevent the spread of the disease. Posters, TV programs and advertisements about the disease, its transmission, and prevention methods such as maintenance of good hygiene practices and information about disinfection were broadcasted. The public was informed through social media and the internet. Both private and public companies had to organize training programs for their employees about the virus. The use of masks and adherence to social distancing have been made compulsory by governments, especially in closed areas (4). Emergency services and emergency triage rooms have been restricted worldwide to ensure the isolation and management of COVID-19 patients during the pandemics. While the total number of visits to the emergency department has decreased in this period, the number of patients who were admitted to the hospital with COVID-19 infection related symptoms has increased (5).

As the authors, we think that the educational activities of governmental and private institutions in the pandemic process will have a positive impact on health literacy, globally. We contemplate, that the positive effect on health literacy will improve patient-physician relationships as well as the patients' compliance to treatment and furthermore will decrease the number of emergency department visits, especially for departments with particularly high numbers of patients. We believe that the exact effect of the COVID-19 pandemic on health literacy and patient management in crowded emergency services will be demonstrated through research that is to be carried out after the pandemic.

Conflict of Interest: No conflict of interest was declared by the authors.

\section{REFERENCES}

1. Özdemir S, Akça HŞ, Algın A, Kokulu K. Health Literacy in The emergency department: A cross-sectional descriptive study. Eurasian J. Emerg Med 2020;19(2):94-97.

2. Herndon JB, Chaney M, Carden D. Health literacy and emergency department outcomes: a systematic review. Ann Emerg Med. 2011;57(4):334-345.

3. Khan G, Sheek-Hussein M, Al Suwaidi AR, Idris K, Abu-Zidan FM. Novel coronavirus pandemic: A global health threat. Turk J Emerg Med. 2020;20:55-62.

4. Flaxman S, Mishra S, Gandy A, Unwin H, Coupland H, Mellan T, et al. Estimating the number of infections and the impact of nonpharmaceutical interventions on Covid-19 in 11 European countries. Imperial College London. arXiv.2004,11342. DOI: https://doi.org/10.25561/77731.

5. Cohen BA, Wessling EG, Serina PT, Cruz DS, Kim HS, McCarthy DM, et al. Emergency department operations in a large health system during COVID-19. Am J Emerg Med. (Article in Press) DOI: 10.1016/j.ajem.2020.05.097.

Correspondence: Serdar Özdemir, University of Health Sciences Umraniye Training and Research Hospital, Department of Emergency Medicine, Istanbul, Turkey. E-Mail: dr.serdar55@hotmail.com

Cite this article as: Ozdemir S, Algin A. How will the health literacy and crowded emergency room be affected after the COVID-19 pandemic? Phnx Med J. 2021;3(1):50. 